\title{
Input Factors Affecting of Orange Production in Tuyen Quang Province, Vietnam
}

\author{
Thu Trang Tran Nguyen ${ }^{1,2}$, Thi Minh Hop Ho ${ }^{1}$, Thi Nga Bui ${ }^{3} \&$ Philippe Lebailly ${ }^{1}$ \\ ${ }^{1}$ Economics \& Rural Development, Gembloux Agro-Bio Tech, University of Liege, 5030 Gembloux, Belgium \\ ${ }^{2}$ Faculty of Economic and Business Management, Tan Trao University, Tuyenquang, Vietnam \\ ${ }^{3}$ Faculty of Accounting and Business Management, Vietnam National University of Agriculture, Hanoi, Vietnam \\ Correspondence: Thu Trang Tran Nguyen. E-mail: thutrang027@gmail.com
}

Received: October 1, 2019 Accepted: October 8, $2019 \quad$ Online Published: October 20, 2019

doi:10.5539/ass.v15n11p17 URL: https://doi.org/10.5539/ass.v15n11p17

\begin{abstract}
Orange production in Tuyen Quang province contributed as one of the largest and most productive for the whole national yield in Viet Nam orange production. This study focused on input factors that impact the orange production in Tuyen Quang and econometric modeling of this production for further assessment. Results in this study show that three main inputs impact on orange production, including fertilizer cost, pesticides cost, and hired labor cost. Econometric models were built which were suitable for the studied population.
\end{abstract}

Keywords: orange production, Tuyen Quang, Vietnam, Cobb-Douglas

\section{Introduction}

Orange is the most popular fruit in the world. Not only does it taste delicious, but orange is also rich in vitamin C, folic acid, fiber and minerals (Berk, 2016b). According to analytical results from USDA in 100g citrus containing: $9.35 \mathrm{~g}$ total sugar; $2.4 \mathrm{~g}$ of fiber; $11.75 \mathrm{~g}$ carbohydrates; $53.2 \mathrm{mg}$ of vitamin $\mathrm{C}$ and many other nutritional ingredients (USDA, 2018). Climate is the most powerful natural factor affecting orange tree growth (Berk, 2016a). The orange tree is a fruit tree with a long history of cultivation and is grown in many parts of the world. It requires a high temperature, sunlight and adequate rainfall so commercial oranges come from areas between the 40-degree north latitude and 40-degree south latitude of the equator (Berk, 2016a).

Vietnam has favorable natural conditions for orange production: a tropical monsoon climate, located in Southeast Asia, lasting from $8^{\circ} 10^{\prime}$ North to $23^{\circ} 24^{\prime}$ North (Socialist Republic of Vietnam - Government Portal, 2019). According to FAO statistics, in 2016, worldwide produced 66974.1 million tons of oranges of all kinds, of which Vietnam contributed 520 million tons (FAO, 2017). In Vietnam, the citrus area planting preliminary in 2018 was about 120.8 thousand hectares (General Statistics Office of Vietnam GSO, 2019b). Orange trees are widely cultivated in some Northern Midlands and Mountains provinces and some Southern provinces of Vietnam. In recent years, Tuyen Quang is one of the provinces with large areas and orange production in Vietnam. Due to the climate and soil, orange trees have been popularly grown in Ham Yen District and have become the key fruit tree of the locality for more than a decade. Most of the orange area in Ham Yen District is "Sanh orange" - a local variety of oranges whose name originates from the orange peel when ripe looks like a piece of terracotta. Sanh orange is a sweet orange with a strong sweet taste, and seedy. Preliminary in 2018, the area of oranges in Tuyen Quang province is 8,634 ha, of which the area of oranges in Ham Yen District is 7270 ha - accounting for $84.2 \%$ of the area of orange growing in the whole province (Tuyen Quang Statistic Office, 2019). Orange production in 2018 of Ham Yen District was 75212 tons, accounting for $92.75 \%$ of the total orange production of the province (81 088 tons) (Tuyen Quang Statistic Office, 2019).

The economic value of orange tree has significantly changed the farmers' standard of living here. The number of orange farms granted certificates of farm registration in the district has continuously increased over the years: in 2010, there were 18 farms (Tuyen Quang Statistic Office, 2019); in 2014, 59 farms (People's Committee of Ham Yen District, 2015); in 2017, 113 farms (Tuyen Quang Statistic Office, 2018), and in 2018 were 168 farms (Tuyen Quang Statistic Office, 2019). The farm economy model has been encouraged to develop through the resolution of the Provincial People's Council (No. 10/2014 / NQ-HDND dated 22 $2^{\text {th }}$ July, 2014), the Decision of the Provincial People's Committee (No. 338 / QD-UBND $27^{\text {th }}$ August, 2014). 
The operation of orange farms was assessed to be positive (People's Committee of Ham Yen District, 2018; People's Committee of Ham Yen District, 2015, 2016, 2017). However, there is no study to assess the impact of the inputs on orange production, nor is there any research on modeling the orange production in Ham Yen District. The objective of this study is to assess the impact of the inputs on the orange production and to develop the econometric model of the local orange production, towards building and developing sustainable agriculture.

\section{Methodology}

\subsection{Sample Size and Sampling Methods}

Orange in Ham Yen contributes more than $90 \%$ of the orange production in Tuyen Quang province, 100\% of orange farms are in Ham Yen District (Tuyen Quang Statistic Office, 2018, 2019). Therefore, the target population of this study is the orange farms' owners in Ham Yen District, Tuyen Quang Province.

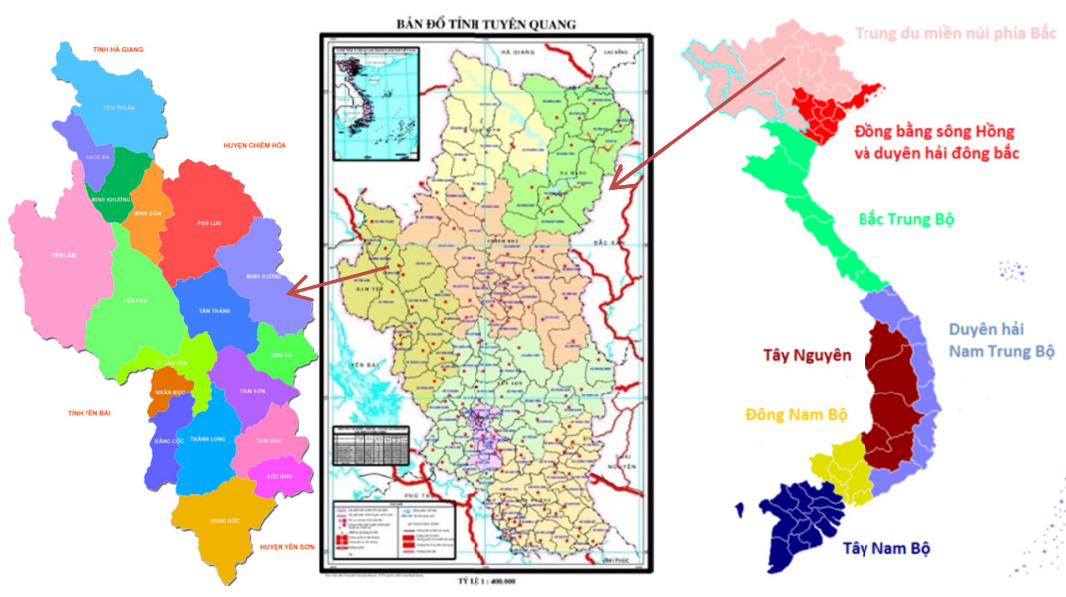

Figure 1. The study site

(Source: (Department of Survey and Mapping Vietnam, 2019; Tuyen Quang Portal, 2019))

Ham Yen district is located in the west of Tuyen Quang province, about $40 \mathrm{~km}$ from Tuyen Quang city, the total natural area is $90093 \mathrm{ha}$, of which agricultural land is 11403 ha, accounting for $12.66 \%$ (Ham Yen District information portal, 2019). Ham Yen district's economy is mainly based on agriculture, of which orange tree is the key crop. The district has 61039 ha of hilly land, suitable for fruit trees (orange, pineapple), industrial crops (citronella, tea), food crops (corn, cassava) (Ham Yen District information portal, 2019).

The farm economy model, in which orange farms account for a high proportion, contributes positively to the socio-economic development of the District. The operation of farms has helped create jobs for family labors, seasonal labors in caring and harvesting oranges (People's Comittee of Ham Yen District, 2019). To be granted a Farm Certificate, farms need to meet the criteria of the farm according to current regulations: Minimum area of 2.1 hectares and the value of goods output of at least 700 million per year (Ministry of Agriculture and Rural Development of Vietnam, 2011).

The sample unit of the study is an individual farm owner. The minimum number of samples is determined by the formula (Aday \& Cornelius, 2006):

$$
n=\frac{z^{2} p q}{e^{2}}
$$

Where: $\mathrm{n}=$ the minimum sample size, $\mathrm{z}=$ distribution value corresponding to the selected reliability, $\mathrm{p}=$ estimated percentage of certified farms in the total of farms that meet the criteria for being granted a farm registration certificate, $\mathrm{q}=1-\mathrm{p}, \mathrm{e}=$ allowed error.

Results from the pilot survey indicate that $\mathrm{p}=0.93$, for $95 \%$ confidence level, the allowed error is $5 \%$, the minimum number of samples is determined as:

$$
n=\frac{1.96^{2} \times 0.93 \times 0.07}{0.05^{2}} \approx 100
$$

This study based on random sample selection method (Kothari, 2004) in the orange zone communes of Ham Yen District. A structured questionnaire had been created after in-depth review of the literature and trial interviews 
with orange farm owners in the study area (Cooper, 2011). Official interviews had been conducted from April to June 2019. 107 valid questionnaires were collected. Data was analyzed by Excel and SPSS 20 software.

\subsection{Model and Variables}

Economic theory shows that the output is the combination of all inputs. Many studies use Cobb-Douglas production functions to analyze production efficiency, especially in agricultural production (Hossain, Alam, \& Uddin, 2015; Moghaddasi \& Pour, 2016; Mohammadshirazi, Akram, Rafiee, \& Bagheri Kalhor, 2015; Qasemi-Kordkheili, Asoodar, \& Kazemi, 2013). Cobb-Douglas production function can fully reflect the data:

$$
Y=A L^{\alpha} K^{\beta}
$$

Where: $\mathrm{Y}=$ total production in a year, $\mathrm{L}=$ labor input, $\mathrm{K}=$ capital input, $\mathrm{A}=$ total factor productivity, $\alpha$ and $\beta$ are the output elasticities of capital and labor, respectively.

The Cobb-Douglas production function is written in a linear format that applies to orange farms in the study area as follows:

$$
\ln \left(Y_{i}\right)=\beta_{0}+\sum_{j=1}^{k} \beta_{j} \ln \left(X_{j i}\right)+e_{i}
$$

Where: $i$ denotes the $i$-th farm in the sample; $Y_{i}$ represents total value of orange production on the $i$-th farm, in 1 $000 \mathrm{VND}$ (Vietnamese currency unit); $\mathrm{X}_{\mathrm{ji}}$ represents the $\mathrm{j}$-th cost to produce an orange crop on the $\mathrm{i}$-th farm (in VND 1,000); $\beta_{\mathrm{j}}$ with $\mathrm{j}=1,2,3, \ldots, \mathrm{k}$ : unknown parameters for the production function.

\section{Results and Discussion}

\subsection{The Orange Farms' Owners}

The survey results show that the average age of orange farmers is quite high, 47.75 years old. The average number of years of experience growing oranges is 19.79 years. However, the average educational level of these farm owners is quite low, corresponding to the high school level.

Applying the age group division of General Statistics Office of Vietnam (General Statistics Office of Vietnam GSO, 2019a) the orange farm owners in the sample are divided into two age groups: from 25 to 49 years old and over 50 years old. Divide the samples according to orange farming experience into three groups: under 10 years, from 10 to 20 years and over 20 years of experience corresponding to the common classification in the locality. Orange farm owners are divided into three groups corresponding to the education system in Vietnam. The results are shown in Table 1:

Table 1. Demographic characteristics of the orange farms' owners

\begin{tabular}{cccc}
\hline Characteristics & Category & Frequency & Percent \\
\hline \multirow{3}{*}{ Age distribution } & From 25 to 49 years old & 63 & 58.9 \\
& Over 50 years old & 44 & 41.1 \\
& Total & 107 & 100.0 \\
& Under 10 years & 4 & 3.7 \\
Experience distribution & From 10 to 20 years & 54 & 50.5 \\
& Over 20 years & 49 & 45.8 \\
& Total & 107 & 100.0 \\
& Primary schooling & 10 & 9.3 \\
Education distribution & Junior secondary schooling & 67 & 62.6 \\
& Secondary schooling & 30 & 28.0 \\
& Total & 107 & 100.0 \\
\hline
\end{tabular}

Source: Surveyed data (2019)

Table 1 presents some basic information about orange farm owners in Ham Yen District from the sample. 58.9\% of farmers are between 25 and 49 years old, $41.1 \%$ of farm owners are over 50 years old. Only $3.7 \%$ of farm owners have experience of growing oranges for less than 10 years, $50.5 \%$ of farmers have 10 to 20 years of experience in growing oranges, and $45.8 \%$ of farmers have been growing oranges with more than 20 years. However, only $28 \%$ of farm owners have a secondary education, and the remaining $72 \%$ have lower education levels. Due to low education levels, farmers have difficulty accessing and applying new technologies to 
production as well as diversifying orange consumption channels to bring higher economic efficiency.

\subsection{General Production Situation}

With its high economic value, in recent years, orange growing area and orange production have increased sharply in Ham Yen district. Specifically, in the last five years (from 2014 to 2018), the area of oranges has increased by 1.58 times and orange production has increased by 1.83 times.

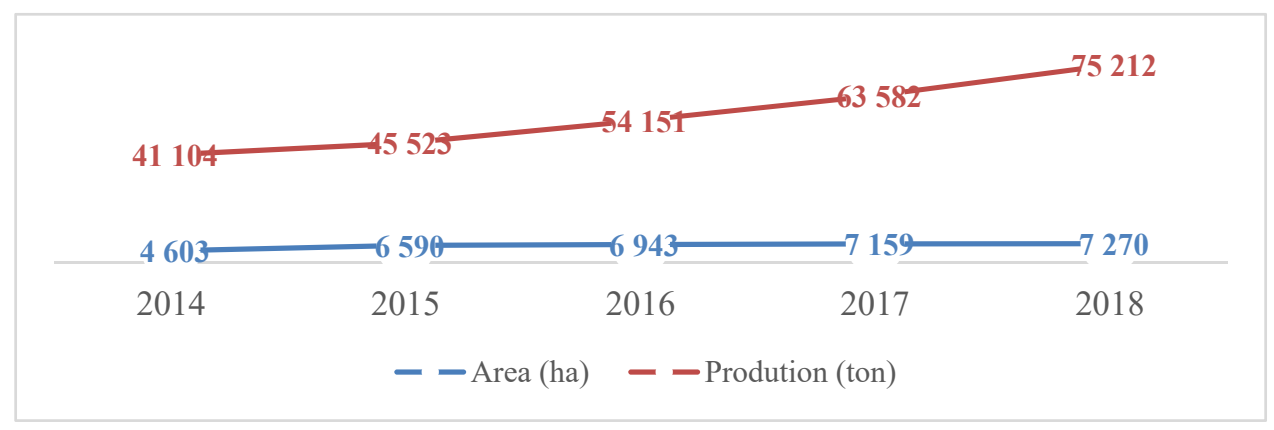

Figure 2. Area of oranges and annual production of oranges

(Source: (Tuyen Quang Statistic Office, 2018, 2019))

Figure 2 shows that annual orange production increases faster than the planting area. This may be a sign that orange productivity in the district has increased over the years from 2014 to 2018. This is a good sign. However, to assess whether or not orange production efficiency increases, further research is needed.

Table 2. Production result for the 2018-2019 crop

\begin{tabular}{ccc}
\hline Orchard area (ha) & Yield (ton/ha/year) & Turnover (Mil.VND) \\
\hline 5589 & 22022 & 642355 \\
\hline
\end{tabular}

Source: Surveyed data (2019)

The average orchard area of the farms in the sample is 5.59 ha. In the crop of 2018/2019, the average yield of the orange farms surveyed reached 22.02 tons/ha/year, the average revenue of the farms reached 642 million VND/year. The 2018/2019 crop is considered to be highly productive. However, the price of oranges is low, so the revenue from orange production is not as high as in the previous period.

Table 3. Orange yield in comparison

\begin{tabular}{ccc}
\hline Location & Yield (ton/ha/year) & Source \\
\hline Surveyed site & 22.02 & Surveyed data, 2019 \\
Vietnam & 13.54 & (General Statistics Office of Vietnam, 2019) \\
USA & 21.70 & (N. A. S. S. USDA, 2018) \\
\hline
\end{tabular}

Comparing the average orange yield of farms interviewed with the national average orange yield and the orange yield in the US, the result shows that: Orange yield in Ham Yen District is 1.63 times higher than the national average of citrus, equivalent to citrus production in the US. The survey results also show that if the weather is favorable, in the future, the orange yield in Ham Yen District can be further improved.

\subsection{Costs at Orange Farm}

Fieldwork results revealed actual cost factors incurred at orange farms are:

Fertilizers cost: Includes all expenses for buying lime, organic and inorganic fertilizers. The content of this expense is consistent with the theory and practice of citrus production (Berk, 2016a). Due to incomplete recording, the data collected is mainly the amount spent to buy fertilizer remembered and provided by the farm owners, without detailed data on the volume and unit price of each fertilizer used.

Pesticide costs: The cost of buying pesticides, fungicides, and herbicides (Berk, 2016a). In this study, the data collected from farm owners is the amount spent on pesticides for the whole crop, there is no detailed data for the price and quantity of each pesticide used.

Labor costs: Farms make the most of family labor in orange production. This part of labor is not paid. Hired labor costs include two parts: fixed labor cost and seasonal labor cost. In particular, the fixed hired labor cost is 
the amount to pay for permanent labors at the farm year-round, the range from 35-45 million VND/ year/ two people (People's Comittee of Ham Yen District, 2019); the cost of hiring seasonal labors is the cost for labors to harvest and transport oranges from the mountains to the point of sale and the costs of hiring sprayers and cleaning the orchard when necessary.

Interest cost: Interest is paid annually on existing loans of the farm. Some borrowed money under the provincial incentive program with preferential interest rates for three years, others borrowed money for normal business. The survey results show that the preferential interest rate is applied at $4.2 \%$ for three years, each farm can borrow up to 500 million VND.

Tools cost: The cost of buying hoes, lawnmowers, sprayers, etc., and the cost of repairing and maintaining existing agricultural equipment on the farm.

Fuel energy cost: The cost to buy fuel for the use of agricultural equipment.

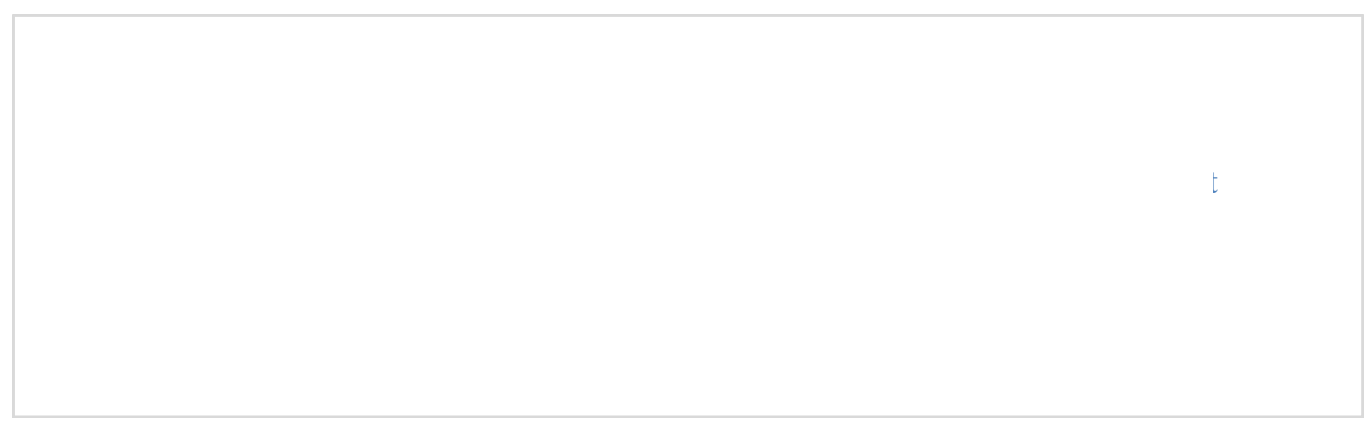

Figure 3. Average input cost per hectare of orchard

(Source: Surveyed data, 2019)

In the study area, hired labor cost, fertilizer cost, and pesticides cost account for a high proportion. The cost of hiring people to harvest and transport oranges to the point of sale accounts for a high proportion of the hired labor cost, normally, farm owners have to pay from $600 \mathrm{VND}$ to $1000 \mathrm{VND}$ for each kilogram of orange cut and delivered to the point of sale. Fertilizer cost includes the cost of buying organic fertilizer, inorganic fertilizer, and lime powder. Pesticides cost includes expenses for pesticides, herbicides, fungicides, etc. Currently, orange farms in the study area without high-value agricultural machinery are ranked as fixed assets. Common agricultural machine are sprayers, lawn generators, and pumps, and the procurement and repair costs of these machines constitute the tools cost. Fuel energy cost is the amount of money to buy oil and gasoline to run agricultural machines. Interest expenses did not arise on all farms, only 26 of the 107 interviewed farms had this cost. Irrigation water costs are not incurred due to local climatic conditions suitable for orange tree development and growth. Moreover, all farms have plumbing systems from the mountains to irrigate oranges when it is too dry.

Summary of average cost factors on farms surveyed per farm, per hectare of orange orchard and per kilogram of oranges are presented in Table 4:

Table 4. Cost factors at farms surveyed

\begin{tabular}{ccccc}
\hline Cost factors & $\begin{array}{c}\text { Cost average per farm } \\
\text { (Thous.VND/farm) }\end{array}$ & $\begin{array}{c}\text { Cost average per hectare } \\
\text { (Thous.VND/ha) }\end{array}$ & $\begin{array}{c}\text { Cost average per tree } \\
\text { (Thous.VND/tree) }\end{array}$ & $\begin{array}{c}\text { Cost average per kg of orange } \\
\text { (Thous.VND/kg) }\end{array}$ \\
\hline Fertilizers cost & 76242.99 & 13642.14 & 52.92 & 0.70 \\
Pesticides cost & 77345.79 & 13839.46 & 53.68 & 0.71 \\
Hired labor cost & 115102.80 & 20595.32 & 79.89 & 1.06 \\
Interest cost & 7210.10 & 1290.10 & 5.00 & 0.07 \\
Tools cost & 5542.06 & 991.64 & 3.85 & 0.05 \\
Fuel energy cost & 5098.13 & 912.21 & 3.54 & 0.05 \\
Total & 286541.88 & 51270.87 & 198.87 & 2.63 \\
\hline
\end{tabular}

(Source: Surveyed data, 2019)

The total average cost of each farm is 286.54 million VND, the average cost per hectare of orange orchards is 51.27 million VND, the average cost per orange tree is 198.87 thousand VND and the average cost to produce 1 $\mathrm{kg}$ of oranges is 2.63 thousand VND. The average selling price of oranges in the 2018-2019 crop on farms is 5.96 thousand $\mathrm{VND} / \mathrm{kg}$. Compared to previous years, the average price of oranges decreased, the actual profit was lower than the expected profit of the farmers, but the orange tree is still a high economic value crop in the 
locality. The area of oranges planted is forecast to continue to increase while the market for products is unstable (People's Comittee of Ham Yen District, 2019).

\subsection{Model of Orange Production Function}

The three main costs from fertilizer, pesticide and outsourced labor account for $94 \%$ of the average input cost of orange production, this study used regression analysis with three independent variables. Cobb-Douglas production function model was built:

$$
\ln \left(Y_{i}\right)=\beta_{0}+\beta_{1} \ln \left(\text { Fert }_{i}\right)+\beta_{2} \ln \left(\text { Pest }_{i}\right)+\beta_{3} \ln \left(\text { Labor }_{i}\right)+e_{i}
$$

Where:

$\mathrm{Y}_{\mathrm{i}}$ represents total value of orange production of the $\mathrm{i}$-th farm $(i=\overline{1 ; 107})$;

Fert $_{i}$ represents Fertilizer cost of the i-th farm;

Pest $_{\mathrm{i}}$ represents pesticides cost of the i-th farm;

Labor $_{i}$ represents the outsourced labor cost of the i-th farm;

$\mathrm{e}_{\mathrm{i}}$ represents the random error.

Using SPSS 20 software to regress the model, the results are summarized in Table 5:

Table 5. Model summary ${ }^{\mathrm{b}}$

\begin{tabular}{cccccc}
\hline Model & $\mathrm{R}$ & $\mathrm{R}$ Square & Adjusted R Square & Std. Error of the Estimate & Durbin-Watson \\
\hline 1 & $.808^{\mathrm{a}}$ & .653 & .643 & .247 & 2.048 \\
\hline
\end{tabular}

a. Predictors: (Constant), lnLabor, $\operatorname{lnFert}$, lnPest

b. Dependent Variable: $\ln Y$

Table 5 shows that the three independent variables included in the model explained $64.3 \%$ of the variation of the dependent variable, the remaining $35.7 \%$ was due to non-model variables and random errors.

Using Durbin-Watson test to detect whether or not there exists a first-order correlation in the model. With $\mathrm{k}=3$, $\mathrm{n}=107$, we have $\mathrm{d}_{\mathrm{L}}=1.6277, \mathrm{~d}_{\mathrm{U}}=1.7428$, the Durbin-Watson value of the test is 2.048. Attached to the Durbin-Watson value bar, $\mathrm{d}_{\mathrm{U}}<2,048<4-\mathrm{d}_{\mathrm{U}}$. Thus, without the first-order correlation in the model, the data collected is good, the value of the test is reliable.

$$
\begin{array}{lllllll}
1.6277 & 1.7428 & \mathrm{~d}_{\mathrm{U}} & 2.048 & 2.2572 & 2.3723 & \\
\hline 0 & \mathrm{~d}_{\mathrm{L}} & \mathrm{d}_{\mathrm{U}} & 2 & 4-\mathrm{d}_{\mathrm{U}} & 4-\mathrm{d}_{\mathrm{L}} & 4
\end{array}
$$

Table 6. ANOVA ${ }^{\mathrm{a}}$

\begin{tabular}{ccccccc}
\hline & Model & Sum of Squares & df & Mean Square & F & Sig. \\
\hline \multirow{2}{*}{1} & Regression & 11.825 & 3 & 3.942 & 64.546 & $.000^{\mathrm{b}}$ \\
& Residual & 6.290 & 103 & .061 & & \\
& Total & 18.116 & 106 & & & \\
\hline
\end{tabular}

a. Dependent Variable: $\ln Y$

b. Predictors: (Constant), lnLabor, $\operatorname{lnFert,~} \ln$ Pest

Using the $\mathrm{F}$ test to test the relevance of the regression model with the target population, Table 6 shows sig. value of test $\mathrm{F}$ is $0.000<0.05$. Thus, the linear regression model built consistent with the population in the study area.

To test the influence of each independent variable in the model, t-test for each independent variable is used. The results are shown in Table 7 :

\begin{tabular}{|c|c|c|c|c|c|c|c|c|}
\hline \multirow{2}{*}{\multicolumn{2}{|c|}{ Model }} & \multicolumn{2}{|c|}{ Unstandardized Coefficients } & \multirow{2}{*}{$\frac{\text { Standardized Coefficients }}{\text { Beta }}$} & \multirow{2}{*}{$\mathrm{t}$} & \multirow{2}{*}{ Sig. } & \multicolumn{2}{|c|}{ Collinearity Statistics } \\
\hline & & $\mathrm{B}$ & Std. Error & & & & Tolerance & VIF \\
\hline & (Constant) & 4.159 & .663 & & 6.276 & .000 & & \\
\hline \multirow{3}{*}{1} & $\operatorname{lnFert}$ & .287 & .093 & .300 & 3.086 & .003 & .358 & 2.797 \\
\hline & $\ln$ Pest & .310 & .086 & .351 & 3.601 & .000 & .356 & 2.813 \\
\hline & lnLabor & .214 & .067 & .253 & 3.184 & .002 & .534 & 1.873 \\
\hline
\end{tabular}

Table 7. Coeficients ${ }^{\mathrm{a}}$

a. Dependent Variable: $\ln Y$ 
Test results show sig values. $<0.05$, means that the three independent variables included in the model have significant explanations for the dependent variable. Small VIF coefficients indicate that no multi-collinearity is detected, independent variables are not interdependent. The beta coefficient reveals the cost of plant protection which most affects the change in orange production value.

\section{Conclusion}

In this study, the impact of the input cost factors on the orange production value has been studied and conclude: Cobb-Douglas production function model for the orange farms in Ham Yen District, Tuyen Quang Province, Vietnam was built with $95 \%$ confidence level as:

$$
\ln \left(Y_{i}\right)=4.159+0.287 \ln \left(\text { Fert }_{i}\right)+0.31 \ln \left(\text { Pest }_{i}\right)+0.214 \ln \left(\text { Labor }_{i}\right)+e_{i}
$$

Among the cost factors of farms:

The average pesticides cost accounts for a high proportion, an average of 13.84 million VND/ha. The use of chemicals to fight pests and diseases is simple, has quick effects, but requires special care. Using the same pesticide repeatedly may promote development of pest resistance and the proliferation of resistant species (Berk, 2016a). To achieve sustainable development, integrated pest management (IPM), which means careful consideration of all available plant protection methods and subsequent integration of appropriate measures that discourage the development of populations of harmful organisms and keep the use of plant protection products and other forms of intervention to levels that are economically and ecologically justified and reduce of minimize risks to human health and the environment (European Commission, 2019).

Hired labor costs account for up to $40 \%$ of total costs. This is a cost-saving if the farms can mechanically transport oranges from the orchard to the selling point. The use of machinery in transporting orange will increase fuel energy costs and agricultural machinery costs but will significantly save outsourcing labor costs and will save time to transport products to the selling point. Can refer to the way of custard apple growers in Lang Son which is a locality with similar terrain conditions to the study area: farmers have had the initiative to transport the custard apple from the mountains down by cable and pulley systems. The initial investment cost is not much, but the effect is very significant, saving the majority of outsourced labor costs, improving fruit harvest productivity.

Author contributions: Philippe Lebailly and Thi Nga BUI: conceptualization, methodology, supervision; Thu Trang TRAN NGUYEN: writing-original draft preparation, writing-review and editing; Thi Minh Hop HO: writing-review and editing.

Conflicts of Interest: The authors declare no conflict of interest.

\section{References}

Aday, L. A., \& Cornelius, L. J. (2006). Designing and Conducting Health surveys A Comprehensive Guide (3rd ed.). United States of America: John Wiley \& Son, Inc.

Berk, Z. (2016a). Chapter 4 - Agricultural production practice. In Z. Berk (Ed.), Citrus Fruit Processing (pp. 65-82). San Diego: Academic Press.

Berk, Z. (2016b). Chapter 13 - Nutritional and health-promoting aspects of citrus consumption. In Z. Berk (Ed.), Citrus Fruit Processing (pp. 261-279). San Diego: Academic Press.

Cooper, D. R. S. (2011). Business research methods (12th ed.).

Department of Survey and Mapping Vietnam. (2019). Administrative map of Socialist Republic of Vietnam. Retrieved from https://www.bandovn.vn/vi/page/mau-ban-do-hanh-chinh-nuoc-cong-hoa-xa-hoi-chu-nghiaviet-nam-181?AspxAutoDetectCookieSupport=1

European Commission. (2019). Integrated Pest Management (IPM). Retrieved from https://ec.europa.eu/food/ plant/pesticides/sustainable_use_pesticides/ipm_en?fbclid=IwAR23xIj_2GW6f9S4JijShijKfhCcfq2umfclO H2D5DPda5YSlEiy5X1wnoE

FAO. (2017). Citrus fruit fresh and processed statistical bulletin 2016. Retrieved from http://www.fao.org/3/a-i8092e.pdf

General Statistics Office of Vietnam. (2019). Statistical Yearbook of Vietnam 2018. Vietnam: Statistical Publishing House.

General Statistics Office of Vietnam GSO. (2019a). Labour force at 15 years of age and above by age group. Retrieved from https://www.gso.gov.vn/default_en.aspx?tabid=774 
General Statistics Office of Vietnam GSO. (2019b). Statistical data: Planted area of main perennial crops. Retrieved from https://www.gso.gov.vn/default.aspx?tabid=717

Ham Yen District information portal. (2019). Natural conditions of Ham Yen District. Retrieved from http:/hamyen.org.vn/gioi-thieu/dieu-kien-tu-nhien.html

Hossain, M., Alam, M., \& Uddin, M. (2015). Application of Stochastic Frontier Production Function on Small Banana Growers of Kushtia District in Bangladesh. Journal of Statistics Applications \& Probability, 4, 337-342. https://doi.org/10.12785/jsap/040218

Kothari, C. R. (2004). Research methodology Methods and Techniques (2nd ed.). India: New Age International limited.

Ministry of Agriculture and Rural Development of Vietnam. (2011). Circulars: Provisions on criteria and procedures for certification of farm economy. (27/2011/TT-BNNPTNT). Vietnam

Moghaddasi, R., \& Pour, A. A. (2016). Energy consumption and total factor productivity growth in Iranian agriculture. Energy Reports, 2, 218-220. https://doi.org/10.1016/j.egyr.2016.08.004

Mohammadshirazi, A., Akram, A., Rafiee, S., \& Bagheri Kalhor, E. (2015). On the study of energy and cost analyses of orange production in Mazandaran province. Sustainable Energy Technologies and Assessments, 10, 22-28. https://doi.org/10.1016/j.seta.2015.01.007

People's Comittee of Ham Yen District. (2018). Report: Implementation results in 2017, plan for implementation in 2018 a number of contents in the field of cooperative and farm economy (79/BC-HDND).

People's Comittee of Ham Yen District. (2019). Report: Implementation results in 2018, plan for implementation in 2019 a number of contents in the field of cooperative and farm economy.

People's Committee of Ham Yen District. (2015). Report: Evaluate the results of production and business of farms 2014.

People's Committee of Ham Yen District. (2016). Report: Evaluate the results of production and business of farms 2015.

People's Committee of Ham Yen District. (2017). Report: evaluate the results of production and business of farms 2016 (11/BC-UBND).

Qasemi-Kordkheili, P., Asoodar, M., \& Kazemi, N. (2013). Orange production assessment and analysis of the relationship between energy input and yield in the sari region of Iran. Elixir Agriculture, 64, 18871-18879.

Socialist Republic of Vietnam - Government Portal. Overview on Vietnam geography. Retrieved from http://www.chinhphu.vn/portal/page/portal/English/TheSocialistRepublicOfVietnam/AboutVietnam/About VietnamDetail? categoryId $=10000103$ \&articleId $=10000505$

Tuyen Quang Portal. (2019). Administrative map of Tuyen Quang. Retrieved from https://.facebook.com/l. php? $\mathrm{u}=\mathrm{http} \% 3 \mathrm{~A} \% 2 \mathrm{~F} \% 2 \mathrm{Ftuyenquang}$.gov.vn\%2FPages\%2Fgioi-thieu.aspx\%3FItemID\%3D6\%261\%3DGio ithieu\%26fbclid\%3DIwAR3FV_BJ_841e2WfJwSHxmN8c1FcbMliX12ZbjxwwbqSwGhrsfENxUVCS0o\& $\mathrm{h}=$ AT37GF1QBMMZEXCHT4yaxÜqmtFwNVUM855VCmc18HEzPTGR_bt_fdiBg9rwieFJGEUkKegln giFrPiVs35J1CxbPRovvDMsIP0ghyBrjCap-yxkDor6e6qjmvU1QZXgxNI

Tuyen Quang Statistic Office. (2018). Tuyen Quang Statistical Yearbook 2017. Vietnam: Statistical Publishing House.

Tuyen Quang Statistic Office. (2019). Tuyen Quang Statistical Yearbook 2018. Statistical Publishing House.

USDA. (2018). Statistics Report: 09200, Oranges, raw, all commercial varieties. Retrieved from https://ndb.nal.usda.gov/ndb/search/list/?manu=\&fgcd=\&ds=\&qlookup=Oranges, \%20raw,\%20all\%20com mercial\%20varieties

USDA, N. A. S. S. (2018). Citrus fruits 2018 summary (1948-9048).

\section{Copyrights}

Copyright for this article is retained by the author(s), with first publication rights granted to the journal.

This is an open-access article distributed under the terms and conditions of the Creative Commons Attribution license (http://creativecommons.org/licenses/by/4.0/). 